\title{
Veri Zarflama Analizi ile Etkinlik Ölçümü: İzmir İli Devlet Hastanelerinde Bir Uygulama ${ }^{1}$
}

\author{
Measuring Efficiency with Data Envelopment Analysis: An Application in İzmir \\ Province State Hospitals
}

İlknur KAR ${ }^{2}$, Erhan DEMIREL İ

Öz

Amaç: $\mathrm{Bu}$ araştırma ile İzmir ilinde faaliyet gösteren tüm kamu hastanelerinin göreceli etkinliklerinin değerlendirilmesi amaçlanmaktadır. Bu kapsamda karar verme birimlerinin ölçeğe göre sabit getiri ve ölçeğe göre değişken getiri varsayımları altında etkinliklerinin ölçülmesi, ölçek etkinliğinin hesaplanması ve etkin olmayan birimlerin etkin düzeye getirilebilmesi için yapılması gereken iyileştirmelerin tespit edilmesi amaçlanmaktadır. Ayrıca hesaplanan süper etkinlik skorları aracılığıyla da etkin karar verme birimlerinin kendi içerisindeki sıralamasını ortaya koymak amaçlanmıştır.

Tasarım/Yöntem: Dea-Solver paket programı kullanılarak 20142015-2016 yıllarına ait girdi ve çıktı değişkenleri aracılığıyla hastanelerin etkinlik skorları hesaplanmış ve incelenen yıllar içerisindeki değişim incelenmiştir. Analizler girdi odaklı yaklaşımla ölçeğe göre sabit getiri ve değişken getiri varsayımı altında ayrı ayrı gerçekleştirilmiştir.

Bulgular: Yapılan analizler sonucunda ölçek etkin bulunan hastane sayıs1 2014 yılında 8, 2015 yılında 10, 2016 yılında ise 6 olarak bulunmuştur. İzmir ilinde faaliyet gösteren kamu hastanelerinin etkinlik ortalaması skorları 2014 yılından 2015 yılına gelindiğinde artış gösterirken, 2016 yılında bir önceki yıla göre azalış göstermiştir.

Sınırlılıklar: $\mathrm{Bu}$ çalışma sadece İzmir ilinde yer alan Sağlık Bakanlığı Hastanelerini kapsamakta olup farklı girdi ve çıktı bileşimlerine sahip olan Ağız ve Diş Sağlığı Merkezleri çalışma kapsamına alınmamıştır. Çalışma yalnızca 2014, 2015 ve 2016 yıllarına ait etkinlik sonuçlarını ifade etmektedir.

Özgünlük/Değer: Sağlık kurumlarının etkinliklerinin değerlendirilmesinde veri zarflama analizi kullanımı son yıllarda yaygınlaşmış olsa da bu çalışmada İzmir ilinin tüm kamu hastanelerinin analize dahil edilmiş olması il düzeyinde bir etkinlik ölçümü sağlamaktadır. Çalışma bulgularının kamu sağlık yöneticilerine stratejik plan ve programlarında katkı sağlaması beklenmektedir.

Anahtar Kelimeler: Etkinlik Ölçümü, Veri Zarflama Analizi, Kamu Hastaneleri

\section{Abstract}

Purpose: In this study it is aimed to assess relative efficiency of all public hospitals operating in İzmir province. In this context, it is aimed to measure efficiency of decision making units in prospect of constant return to scale and variable return to scale, calculate to scale efficiency, determine to improvements for bring inefficient units to the efficient level. It is also aimed to determine the ranking of effective decision-making units within themselves through the calculated super efficiency scores.

Design/Methodology: By using the Dea-Solver package program, efficiency scores of the hospitals were calculated by using the input and output variables for the years 2014-2015-2016 and the trend over the years was examined with using Dea-Solver package programme. Analyzes were carried out separately with the inputoriented approach under the assumption of constant return and variable return to scale.

Findings: As a result of the analyzes conducted, the number of the scale efficient hospitals is found to be 8 in 2014, 10 in 2015 and 6 in 2016, with effective results on the assumption of constant return to scale and variable return to scale. The average efficiency scores of public hospitals operating in İzmir province increased from 2014 to 2015 , but it is decreased in 2016 compared to the previous year.

Limitations: The fact that the sample consists of students who are only in Gaziantep and the use of three variables as a brand component are the limitations of the study.

Originality/Value: Although the use of data envelopment analysis in evaluating the efficiency of health institutions has become widespread in recent years, the inclusion of all public hospitals in İzmir province provides an efficiency measure at the provincial level in this study. The findings of the study are expected to contribute to public health managers in their strategic plans and programs.

Keywords: Efficiency Measurement, Data Envelopment Analysis, Public Hospitals

\footnotetext{
${ }^{1} \mathrm{Bu}$ çalışma sorumlu yazarın "Veri Zarflama Analizi ile Etkinlik Ölçümü: İzmir İli Devlet Hastanelerinde Bir Uygulama" başlıklı yüksek lisans tezinden türetilmiştir.

2 Doktora Öğrencisi, Sakarya Üniversitesi, İşletme Enstitüsü, Sağlık Yönetimi Bölümü, ilknur.kar@ogr.sakarya.edu.tr, ORCID: 0000-0003-0177-6559

${ }^{3}$ Prof. Dr., Dokuz Eylül Üniversitesi, İktisadi ve İdari Bilimler Fakültesi, İşletme Bölümü, erhan.demireli@deu.edu.tr, ORCID: 0000-0002-3457-0699
} 


\section{GİRIŞ̧}

Sağlık hizmetleri, bireylerin sağlıklarının korunması, hasta olduklarında tedavi edilmeleri, fiziksel ve ruhsal yönden rehabilitasyonlarının sağlanması amacıyla sunulan hizmetlerdir. Bireylerin sağlıklı bir yaşam sürdürebilmesi çevre, insan biyolojisi, kalıtım ve yaşam biçimi gibi birçok faktörün bileşkesine bağlıdır. Bu faktörlerin yanında sağlık sistemlerinin etkin şekilde kurulmuş ve işletiliyor olması da sağlığın belirleyicileri arasında gösterilmektedir. Sağlık hizmet sunucusu olarak hastaneler sağlık sistemlerinin temel yapı taşı olarak faaliyet göstermektedir. Dolayısıyla hastanelerin sunmuş oldukları hizmette etkinlik ve verimlilik kavramlarını ön planda tutması sürdürülebilirliklerini sağlayacak ve hastaneler toplumun sağlık statüsünü iyileştirme rollerine devam edebilecektir.

Hastaneler, sunulan sağlık hizmetinin niteliğine göre farklı girdi ve çıktı yapılarına sahip karar verme birimleridir. Birinci basamak sağlık kurumlarında girdiler daha çok koruyucu sağlık hizmetlerini sunmaya yönelik olarak çıktılara dönüştürülürken ikinci basamak sağlık kurumlarında tedavi edici hizmetlerde, üçüncü basamakta ise eğitim araştırma faaliyetlerinde çıktılara dönüş̧ürülmektedir.

Sağlık Bakanlığı tarafindan yayımlanan Sağlık İstatistikleri Yıllı̆̆ı'na göre Türkiye'de kamu sağlık harcamalarının artış trendi içinde olması sağlık sektörü için ayrılan kaynakların tahsisat verimliliği ve üretim verimliliği açısından değerlendirilmesini zorunlu kılmaktadır. Toplam sağlık harcamaları içerisinde önemli bir bölümü hastaneler oluşturmaktadır. Sağlıkta dönüşüm programı ile birlikte bireylerin sağlık hizmetlerine daha kolay, daha güvenilir ve daha kaliteli şekilde erişebilir hale gelmesi yıllar itibariyle toplam sağlik hizmetleri talebinde ve bu hizmetlerin tüketim miktarında önemli artışlar yaşanmasına kaynaklık etmiştir. Nüfusun yaşlanması ile birlikte kronik hastalıkların artması, hastaların daha bilinçli tüketiciler hale gelmesi ve sağlı teknolojilerinde yaşanan gelişmeler maliyetlerin artmasına neden olmuştur. Daha fazla hizmet sunumu için daha fazla kaynak tüketiminin gerekli hale gelmesi ile kaynak-sonuç ilişkisi değerlendirilerek daha az maliyetle nasıl daha yüksek sağlık sonuçlarının elde edileceği önemli bir yönetsel problemi doğurmuştur.

Kamu sağlık kurumlarının birincil amacı sunulan hizmetlerden kar elde etmek değildir. Ancak hizmetlerin sürdürülebilirliği açısından minimum maliyetlerle hizmet sunumunu gerçekleştirmek önemli bir verimlilik kaynağı olacaktır. Bu kapsamda Türkiye Kamu Hastaneleri Genel Müdürlügü̈’ne bağlı olarak Verimlilik Daire Başkanlığı çeşitli göstergeler bazında verimlilik ölçme ve değerlendirme faaliyetlerini yürütmektedir. Ancak bu faaliyetler içerisinde kamu hastanelerinin kullanmış olduğu kaynaklar neticesinde sunmuş olduğu çıktıların oranına ilişkin etkinlik değerlendirmesi bulunmamaktadır.

Diğer üretim ve hizmet işletmelerinde etkinlik ya da verimlilik hesaplamaları çok daha eski tarihlere uzanırken sağlık kurumlarında ilk uygulamaları görece daha yeni sayılmaktadır. Hastanelerin insan hayatını kurtaran ve diğer işletmeler gibi birincil önceliğinin verimlilik olmadığını savunan yaklaşım bu gecikmeye neden olsa da sağlık hizmetlerinin sunumunda özel sektörün rolünün artması ve kamu hastaneleri arasında da performans değerlendirme sistemlerinin önem kazanması ile verimlilik ölçümü uygulamaları başlamıştır.

Benzer girdi birimlerini kullanarak benzer çıktılar elde eden karar verme birimlerinin birbirileriyle mukayeseli olarak performansının ölçümünde veri zarflama analizi sıklıkla kullanılan geçerli bir ölçüm aracı olarak kabul edilmektedir. Bu çalışma kapsamında da İzmir ilinde faaliyet gösteren kamu hastanelerinin belirlenmiş olan girdi ve çıktı değişkenleri açısından veri zarflama analizi ile etkinliklerinin değerlendirmesi amaçlanmıştır. Yürütülen girdi odaklı, ölçeğe göre sabit ve ölçeğe göre değişken getiri varsayımları altında incelenen üç yıllık süreç için hastanelerin etkinliklerindeki değişim izlenmiş ve etkin olmayan hastaneler için iyileştirme önerileri sunulmuştur.

\section{VERI ZARFLAMA ANALIZI}

Veri Zarflama Analizi, öncelikle Farrell'in (1957) "Üretim Sinırı" (Production Frontier) kavramını temel alarak Charnes vd.'nin çok sayıda girdi ve çıktısı olan karar birimlerinin göreli etkinliğinin ölçülmesine yönelik 1978 yılında yaptığı çalışmayla ortaya konulmuştur. 1984 yılında ise Banker vd. teknik etkinlik ve ölçek etkinliği ayrımının olduğu BBC (Banker, Charnes, Cooper soyadlarının baş harflerinde oluşan) modeli geliştirmişlerdir (Tütek vd., 2012: 223). Charnes vd. 
tarafından geliştirilen CCR Modeli Ölçeğe Göre Sabit Getiri varsayımıyla analiz yaparken; Banker vd. tarafından ölçeğe göre değişken getiri varsayımını karşılayan BCC modeli geliştirilmiştir (Bakırcı, 2006: 203).

Veri zarflama analizinin öncüleri, fikirlerinin bir grup araştırmacının düşüncelerine ilham vereceğini ve genel kabul gören akademik bir alanı topluca geliştireceğini beklememiştir (Liu vd., 2013: 1). Ancak zamanla VZA, Charnes vd. tarafından ilk uygulamasının başlangıcından (1978) bu yana dört binin üzerinde basılı makale, üç binin üzerinde basılmamış tez ve sunuma sahip zengin bir geçmişe sahiptir. Sağlık alanında da zengin içeriğe sahip olan VZA uygulamaları ülke sağlık sistemlerinin, birinci basamak sağlık hizmetlerinin, toplum sağlığ düzenlemelerinin ve bireysel hekim uygulamalarının etkinliğini değerlendirmede sıklıkla kullanılmıştır (Dilts vd., 2015: 498).

Literatürde yer alan çeşitli çalışmalarda karar verme birimlerinin etkinlik ve verimlilik düzeyinin belirlenmesinde genellikle oran analizi veya regresyon analizi kullanılmıştır. Fakat her iki yöntemin de bazı eksiklikleri bulunmaktadır. İşletmeler arasında kıyaslama yapılmasında bazı kısıtlılıkların olması ve en etkin işletmeleri belirlemede başarılı olmaması karar vericileri alternatif yaklaşımlara yönlendirmiştir. $\mathrm{Bu}$ yönelimin sonucunda ise karar birimlerinin göreli etkinlik hesaplamalarında VZA önemli bir popülerlik kazanmıştır (Özata \& Sevinç, 2010: 91).

VZA parametrik olmayan yöntemler içerisinde en sık kullanılan yöntemlerden biridir. VZA'da çalışılan organizasyona karar verme birimi (KVB) adı verilir. Karar verme biriminin tanımı geniş bir yelpazedeki olası uygulamalar üzerinde oldukça farklılık gösterebilmektedir. Genel olarak bir Karar Verme Birimi, girdileri çıktılara dönüştüren ve etkinliği değerlendirilen birimdir. Yönetimsel uygulamalarda Karar Verme Birimleri, bankalar, mağazalar ve süpermarketler, hastaneler, okullar, halka açık kütüphaneler gibi yapılar olabilmektedir (Cooper vd., 2007: 22). Benzer ürün üreten ekonomik karar verme birimlerinin göreli etkinliklerinin ölçülmesi amacı ile geliştirilmiş doğrusal programlama esaslı bir yöntemdir (Banker, 1992: 74). Charnes vd. tarafından geliştirilmiş olan VZA, genellikle karar verme birimi (KVB) olarak adlandırılan benzer girdi ve çıktı özelliklerine sahip birimlerden oluşan veri setinin görece etkinliğini ölçen parametrik olmayan bir yöntemdir (Kumar \& Gulatı, 2008: 36). Çok sayıda girdi ve çıktı değişkenin olduğu veri setlerinde analizleri gerçekleştirebilmekte ve etkin olmayan karar birimlerini kolaylıkla tespit edebilmektedir (Başkaya \& Akar, 2005: 38; Bayraktutan \& Pehlivanoğlu, 2012: 128). VZA, bir doğrusal programlama tekniğidir. Etkinliği ölçülecek olan homojen yapıdaki karar birimlerini birbirleri ile mukayese eder ve en iyi gözleme sahip firmayı referans (etkinlik sınırı) kabul ederek diğerlerini buna göre değerlendirir (Bakırcı, 2006: 105). Sağlık hizmetinin verimliliğini değerlendirme açısından bakıldığında, KVB'leri ülkedeki eksiksiz bir sağlık hizmeti sistemi, ilçeler, hastaneler, belirli hizmet sağlayıcılar, departmanlar veya bireysel doktorlar dahil olmak üzere farklı sağlık hizmetleri düzeylerini temsil edebilir. KVB'nin verimliliği, verimlilik sınırına olan mesafesini temsil eder. Verimlilik sınırının yeri ve şekli, kullanıcı verilerine ve kullanılan varsayımlara (ölçeğe dönüş türü, girdi veya çıktı yönü) bağlıdır. Verimlilik sınırı, iki boyutlu uzayda elde edilen girdilerin sayısı ile çıktılar arasındaki ilişkiyi çizerek ortaya çıkar. $\mathrm{Bu}$, girdiler ve çıtıllar arasındaki bireysel izleme ilişkilerinin bir kombinasyonudur. Verimlilik sınırının inşası en iyi tahmin ilkesine dayanmaktadır (Stefko vd., 2018: 2-3). Bu teknikte, öncelikle birimin kullandığı kaynakları ve ürün veya hizmetlerini gösteren girdi ve çıkt endeksleri belirlenip hesaplanır, ardından birimlerin verimliliğini hesaplamak için uygun VZA kullanılır. VZA tekniğinin özelliği, karar verme birimlerinin verimliliğini değerlendirdikten sonra her birine özgü düzeltmeler ve iyileştirmeler sunması ve optimum düzeyde girdi ve çıktı elde edilmesi durumunda , bu birimin optimum duruma ulaşmasıdır (Farzianpour vd., 2012: 394).

Analiz sonucunda tespit edilen etkinlik skorları karar verme biriminin kendi üretim fonksiyonu ile ilgili bilgiler verirken aynı zamanda sektördeki karşılaştırmaya tabi tutulan diğer birimlerin de görece durumunu yansıtmaktadır. Hangi birimin ne kadarlık girdi ile ne kadarlık çıktı elde ettiği sorusu bu mukayesede etkin rol oynamaktadır. Dolayısıyla en az girdi miktarı ile en yüksek çıktı miktarını elde eden birimler en iyi olarak belirlenmekte ve kıyaslamalar ona göre yapılmaktadır (Öztürk, 2009: 143).

VZA modelleri ile homojen yapıdaki karar birimlerinin mukayeseli analizi yapılabilir. Her bir karar birimi için model test edilir. Doğrusal programlama sonucunda, amaç fonksiyonu 1'e eşit olan 
karar birimleri "etkin" olarak belirlenirken amaç fonksiyonu 1'e eşit olmayan karar birimleri, etkin karar birimlerinden kendisine uygun olan bir tanesine benzetilmeye çalış1lır. Böylece etkin olmayan her bir birim, etkin hale getirilmiş olur (Bülbül \& Akhisar, 2004: 3). VZA'nın temeli karar verme birimlerinin göreceli etkinliğidir. VZA yöntemi göreceli etkinlikleri ve ölçeğe göre getirileri kıyaslayabilmek ve de optimal değerleri gösterebilmek için ekonometriden marjinal fayda teorisini, ileri matematikten de doğrusal programlama modelini ödünç almıştır (Li vd., 2009: 371).

VZA iki aşamalı olarak etkinliği ölçmektedir. İlk aşamada az girdi bileşimini kullanarak en çok çıktı bileşimini üreten en iyi gözlemleri, ikinci aşamada ise etkin olmayan karar birimlerinin etkinlik sınırına olan uzaklıklarını hesaplar (Yolalan, 1993: 27-28).

\subsection{Veri Zarflama Analizinin Modelleri}

Charnes vd. (1978) CCR olarak bilinen ilk modeli geliştirmiştir. Bu model girdi odaklı ve çıktı odaklı olmak üzere iki sınıfa ayrılmaktadır. Girdi odaklı modeller, çıktı miktarında bir değişim olmadan girdi miktarını minimize etmeyi amaçlarken; çıktı odaklı modeller girdi miktarında bir artış olmadan çıktı miktarını maksimize etmeyi amaçlamaktadır. CCR modeli ölçeğe göre sabit getiri varsayımında hareket etmektedir (Arieh \& Gullipalli, 2012: 13).

Banker, Charnes ve Cooper (1984) CCR modelini ölçeğe göre değişken getiri altında çalışacak şekilde geliştirmiştir. Bu yaklaşım girdi ve çıktı arasında oransal bir değişim olduğunu varsaymaktadır. BCC modeli mevcut DMU'ların konveks gövdesini kapsayan üretim sınırına sahiptir. $\mathrm{Bu}$ sınır, ölçeğe göre değişken getiri özelliklerini sağlayan parçalı doğrusal ve içbükey özelliklere sahiptir (Rajasulochana \& Dash, 2012: 154; Arieh \& Gullipalli, 2012: 13).

CCR ve BCC metotları başta olmak üzere birden çok VZA yöntemi bulunmaktadır. Ölçeğe göre sabit getirili CCR modelinde girdilerde meydana getirilen artış kadar aynı oranda çıktılarda artış meydana gelmektedir. Ölçeğe göre sabit getirili CCR modeli yardımıyla bulunan toplam etkinlik sonuçları, teknik etkinlik ve ölçek etkinlik skorlarını kapsamaktadır. BCC modeli etkin olan ve olmayan karar birimlerini tespit etmekle beraber ölçeğe göre değişken getirinin de yönünü belirtmektedir. Girdi miktarında yaşanan değişimden daha yüksek oranda çıktı miktarında artış görünüyorsa ölçeğe göre artan getiriden bahsedilirken; çıktı miktarında girdi miktarında yaşanan artıştan daha düşük oranda artış yaşanması ölçeğe göre azalan getiriyi ifade edecektir (Baysal, 2010: 26). BBC modeli ile CCR modelindeki ölçeğe göre sabit getiri varsayımı ortadan kaldırıldığından bu model ölçeğe göre artan, azalan ya da sabit getiri durumlarında etkinlik analizi yapılabilmesini sağlamıştır. Sonraki yıllarda farklı VZA modelleri ile farklı çalışmalar yürütülmüş̧ür (Tütek vd., 2012: 223-224).

VZA yönteminde kullanılan girdi ve çıktı sayısının artması grafiksel olarak etkinlik ölçümünü zorlaştırmaktadır. $\mathrm{Bu}$ nedenle Charnes vd.'nin doğrusal programlama temelli geliştirmiş olduğu matematiksel modellerin kullanımı daha yararlıdır. Bu modeller girdi yönelimli ve çıktı yönelimli olarak oluşturulup etkinlik çözümleri hesaplanmaktadır (Yavuz, 2012: 25). Girdiye yönelimli VZA modelleri belirli bir çıktı miktarının en uygun hangi girdi bileşeni ile elde edilebileceğini araştırırken; çıktı yönelimli VZA modelleri belirli bir girdi bileşimi ile nasıl en yüksek miktarda çıktı bileşimi elde edilebileceği üzerinde durmaktadır (Charnes vd., 1981: 669). Etkinlik ölçümü için geliştirilen çeşitli VZA modelleri bulunmaktadır.

\subsubsection{CCR modeli}

CCR modeli ölçeğe göre sabit getiri varsayımı altında, 1978 yılında Charnes vd. tarafından ortaya konmuş bir kesikli programlama modelidir ve bu model doğrusal programlama modeline dönüştürülerek her KVB için çözüm gerçekleştirilir. CCR modeli ölçeğe göre sabit getiri modeli olarak adlandırılır. CCR modelleri ile KVB'lerin TTE değeri elde edilir. CCR modelleri girdi odaklı ve çıktı odaklı olmak üzere iki farklı yapıda oluşturulabilir. Etkin olmama durumu, girdi odaklı modelde girdileri azaltarak (çıktı sabit), çıktı modeli ise çıktıları arttırarak (girdi sabit) giderilmeye çalış1ır (Tütek vd., 2012: 232). CCR yapısını, çoklu çıktı / çoklu girdi durumunu her karar verme birimi için tek bir "sanal" çıtı ve "sanal" girdiye indirgemek olarak yorumlayabiliriz. Belirli bir karar verme birimi için, bu tekli sanal çıktının tekli sanal girdiye oranı, çarpanların bir fonksiyonu olan bir etkinlik ölçütü sağlar. Matematiksel programlama dilinde, bu oran en üst düzeye getirilecek olup, 
değerlendirilmekte olan belirli karar verme birimi için objektif fonksiyonu oluşturmaktadır (Cooper vd., 2007: 7). Etkinlik ölçümü için geliştirilmiş çeşitli VZA modelleri vardır. Sağlık sektöründe ölçeğe göre sabit getiri modeli Özcan ve McCue tarafından çalışılmış ve hastane performansının değerlendirilmesi için önerilmiştir (1996). CCR modeli karar verme birimlerinin etkinliğini ölçeğe göre sabit getiri varsayımıyla değerlendirmektedir. Örneğin, eğer bir faaliyet uygun bölge içerisinde yer alıyorsa faaliyet $(\mathrm{Kx}, \mathrm{Ky})$ de uygun pozitif sayısal K bölgesinde yer alır. Çoğu sağlık kuruluşu için amacın daha az kaynak (yatak sayısı, personel sayısı gibi) kullanarak hastalara daha yüksek düzeyde hizmet vermek olduğu düşünüldügünde girdi odaklı CCR modelleri bu çalışma için daha uygun olmaktadır (Weng vd., 2009: 41). Girdi odaklı ve çıktı odaklı CCR modelleri kesirli programlama modeli olarak aşağıdaki gibi oluşturulur (Cooper vd., 2011: 13).

Tablo 1: CCR Girdi Odakl1 Veri Zarflama Modeli

$$
\begin{aligned}
& \operatorname{Min} \theta-\varepsilon\left(\sum_{i=1}^{m} s_{i}^{-}+\sum_{r=1}^{s} s_{r}^{+}\right) \operatorname{Maxz}=\sum_{r=1}^{s} \mu_{r} y_{r o} \\
& \sum_{j=1}^{n} x_{i j} \lambda_{j}+s_{i}^{-}=\theta \mathrm{x}_{\mathrm{io}} \quad i=1,2, \ldots . . m ; \quad \sum_{r=1}^{s} \mu_{r} y_{r j}-\sum_{i=1}^{m} v_{i} x_{i j} \leq 0 \\
& \sum_{j=1}^{n} y_{r j} \lambda_{j}-s_{r}^{+}=\mathrm{y}_{\text {ro }} \quad r=1,2, \ldots . . s ; \quad \sum_{i=1}^{m} v_{i} x_{i o}=1 \\
& \lambda_{j} \geq 0, \quad j=1,2, \ldots \ldots n ; \quad \mu_{r}, \quad v_{i} \geq \varepsilon>0,
\end{aligned}
$$

\subsubsection{BCC modeli}

Ölçeğe göre değişken getiri modeli olarak adlandırılan BCC modeli 1984 yilında ilk olarak Banker vd. tarafından CCR modellerindeki ölçeğe göre sabit getiri varsayımını ortadan kaldırmak ve ölçeğe göre değişken getiri altında etkinlik analizi yapmak üzere ortaya konmuştur. BCC modelinin, CCR modelinden tek farkı, ölçeğe göre değişken getiri altında analiz yaparken CCR modellerinin dualine konveks kısıtı eklemiş olmasıdır. Girdi odaklı ve çıktı odaklı BCC modelleri kesirli programlama modeli olarak aşağıdaki gibi oluşturulur (Tütek vd., 2012: 236).

Tablo 2: BCC Veri Zarflama Modeli

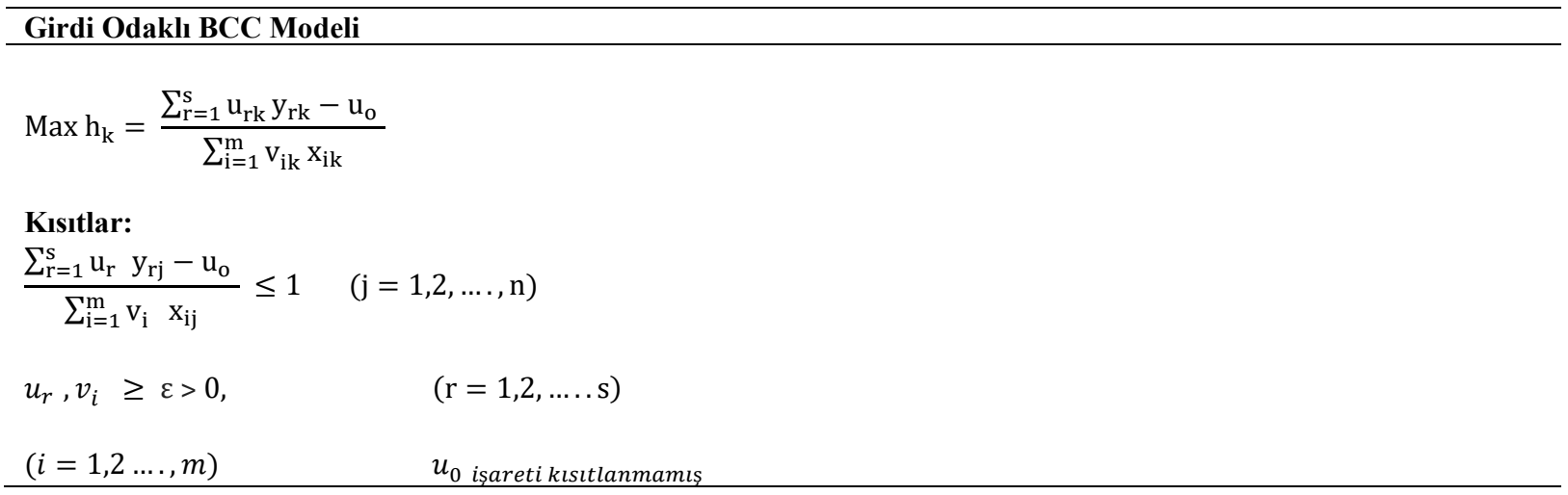

\section{YÖNTEM}

Dea-Solver paket programı kullanılarak 2014, 2015 ve 2016 yıllarına ait girdi ve çıtı değiş̧kenleri aracılığıyla hastanelerin etkinlik skorları hesaplanmış ve incelenen yıllar içerisindeki değişim incelenmiştir. Yapılan analizler girdi odaklı yaklaşımla ölçeğe göre sabit getiri ve değişken getiri varsayımı altında ayrı ayrı gerçekleştirilmiştir. Daha sonra karar verme birimi olan hastanelerin ölçek etkinlikleri CCR ve BCC yaklaşımlarının oranlanması yoluyla hesaplanmış ve gerekli iyileştirme önerileri sunulmuştur. Etkin karar verme birimlerinin kendi içerisindeki sıralamasının tespit edilebilmesi için de paket program aracılığıyla süper etkinlik skorları hesaplanmıştır. 


\subsection{Girdi ve Çıktı Değişkenlerinin Seçilmesi}

VZA'de karar verme birimlerinin göreli etkinlikleri seçilen girdi ve çıktılara göre belirlenmektedir. $\mathrm{Bu}$ nedenle kullanılacak girdiler ve çıtıllar dikkatle seçilmelidir. Girdi ve çıktı seçimi karar verme birimlerinin üretimini yansıtırken en iyi şekilde oluşturulmalıdır. Aksi halde girdi ve çıktı kümesinin eksik veya fazla oluşturulması karar verme birimlerinin etkinliklerini olması gerekenden farklı çıkarabilir (Savaş, 2015: 206). Analizde kullanılan girdi ve çıktıların arasındaki ilişkinin ortaya çıkarılması, girdi ve çıktıların doğru belirlenmesi, üretim aşamasında direkt etkide bulunmayan değişkenlerin elenmesi ve belirlenen tüm girdi çıktılara ait verilerin incelenen tüm karar birimleri için elde edilebilir ve güvenilir olması oldukça önemlidir (Erkorol, 2009: 79). Girdi ve çıktı sayılarının azaltılmasıyla VZA'nın ayrıştırma yeteneği artar. Sonuç olarak girdi ve çıktı sayısının çok fazla olması karar birimleri sayısının da artması gerekliliğini doğurur. Girdi ve çıktıların çok olduğu bir çalışmada verileri seçerken de ölçüm hatalarının yapılmaması oldukça önemli bir faktördür (Öner, 2008: 27).

Tablo 3: Çalışmada Kullanılmasına Karar Verilen Girdi ve Çıktı Değişkenleri

\begin{tabular}{ll}
\hline Girdi Değişkenleri & \\
\hline X1: & Tescilli Toplam Yatak Sayıs1 \\
\hline X2: & Pratisyen ve Uzman Hekim Sayıs1 \\
\hline X3: & Hemşire Sayısı \\
\hline Çıktı Değişkenleri & \\
\hline Y1: & Toplam Ameliyat Sayıs1 \\
\hline Y2: & Toplam Taburcu Olan Hasta Sayıs1 \\
\hline Y3: & Toplam Ayaktan Muayene Sayıs1 (Acil Dahil) \\
\hline
\end{tabular}

VZA yöntemi ile yapılan literatür çalışmaları incelendiğinde girdi ve çıktıların seçiminde farklı değişkenlerin kullanıldığ 1 görülmektedir. Araştırmada kullanılacak değişkenlerin belirlenmesi için ilgili literatür incelenmiş önceki çalışmalar göz önüne alınarak, VZA'da kullanılan genel kabul görmüş değişkenler araştırma kapsamına alınmıştır. Literatür incelemesi sonrasında analizde; tescilli toplam yatak sayısı, pratisyen ve uzman hekim sayısı ve hemşire sayısı değişkenleri girdi olarak, toplam ameliyat sayıs1, toplam taburcu olan hasta sayıs1, toplam ayaktan muayene sayısı (acil dahil) ise çıktı olarak kullanılmasına karar verilmiştir.

\section{BULGULAR}

Çalışma kapsamında yapılan analizler ve hesaplamalar sonucunda çeşitli bulgulara erişilmiştir. Çeşitli yaklaşımlarla etkinlik ölçümleri gerçekleştirilen karar verme birimlerinin 2014, 2015 ve 2016 yıllarına ilişkin ortalama, standart sapma, maksimum ve minimum değerleri Tablo 4'te gösterilmektedir.

Tablo 4: 2014 Yılı Hastanelerin Girdi ve Çıktı Değişkenleri Genel Ortalaması

\begin{tabular}{lcccccc}
\hline & \multicolumn{3}{c}{ Girdi Değişkenleri } & \multicolumn{3}{c}{ Çıktı Değişkenleri } \\
\cline { 2 - 8 } & Hekim Sayısı & $\begin{array}{c}\text { Hemşire } \\
\text { Sayısı }\end{array}$ & $\begin{array}{c}\text { Tescilli Yatak } \\
\text { Sayısı }\end{array}$ & $\begin{array}{c}\text { Muayene } \\
\text { Sayısı }\end{array}$ & $\begin{array}{c}\text { Taburcu } \\
\text { Hasta Sayısı }\end{array}$ & $\begin{array}{c}\text { Ameliyat } \\
\text { Sayısı }\end{array}$ \\
\hline Ortalama & 89,54 & 144,43 & 217,25 & 539561,36 & 12039,86 & 28441,5 \\
\hline Max & 427 & 667 & 1051 & 1842551 & 77161 & 152880 \\
\hline Min & 9 & 13 & 25 & 35330 & 0 & 425 \\
\hline Standart Sapma & 105,5 & 173,96 & 278,82 & 430377,36 & 16510,49 & 32695,06 \\
\hline
\end{tabular}

2014 y1lı İzmir ili genelindeki tüm hastanelerin genel ortalama hekim sayıs1 89,54, ortalama hemşire sayıs1 144,43, ortalama tescilli yatak sayıs1 217,25, ortalama muayene sayıs1 539561,36, ortalama taburcu hasta sayısı 12039,86 ve ortalama ameliyat sayısı 28441,50 olarak hesaplanmıştır.

Tablo 5: 2015 Yı1ı Hastanelerin Girdi ve Çıktı Değişkenleri Genel Ortalaması

\begin{tabular}{lcccccc}
\hline & $\begin{array}{c}\text { Hekim } \\
\text { Sayısı }\end{array}$ & $\begin{array}{c}\text { Hemşire } \\
\text { Sayıs }\end{array}$ & $\begin{array}{c}\text { Tescilli Yatak } \\
\text { Sayısı }\end{array}$ & $\begin{array}{c}\text { Muayene } \\
\text { Sayısı }\end{array}$ & $\begin{array}{c}\text { Taburcu } \\
\text { Hasta Sayısı }\end{array}$ & Ameliyat Sayısı \\
\hline Ortalama & 87,93 & 155,54 & 216,11 & 549893,46 & 11544,82 & 13362,50 \\
\hline Max & 407 & 778 & 1055 & 1796807 & 71848 & 54933 \\
\hline Min & 12 & 12 & 25 & 46753 & 0 & 1181 \\
\hline Standart Sapma & 95,29 & 195,56 & 272,42 & 427548,29 & 15593,27 & 13215,87 \\
\hline
\end{tabular}


2015 y1lı İzmir ili genelindeki tüm hastanelerin genel ortalama hekim sayıs1 87,93, ortalama hemşire sayıs1 155,54, ortalama tescilli yatak sayıs 216,11, ortalama muayene say1s1 549893,46, ortalama taburcu hasta sayıs1 11544,82 ve ortalama ameliyat sayısı 13362,50 olarak hesaplanmıştır.

Tablo 6: 2016 Yılı Hastanelerin Girdi ve Çıktı Değişkenleri Genel Ortalaması

\begin{tabular}{lcccccc}
\hline & Hekim Sayısı & Hemşire Sayısı & $\begin{array}{c}\text { Tescilli Yatak } \\
\text { Sayısı }\end{array}$ & $\begin{array}{c}\text { Muayene } \\
\text { Sayısı }\end{array}$ & $\begin{array}{c}\text { Taburcu Hasta } \\
\text { Sayısı }\end{array}$ & $\begin{array}{c}\text { Ameliyat } \\
\text { Sayısı }\end{array}$ \\
\hline Ortalama & 235,15 & 687118,22 & 11975,07 & 108,67 & 170,78 & 14743,00 \\
\hline Max & 526 & 784 & 1155 & 2416195 & 61748 & 62399 \\
\hline Min & 11 & 15 & 25 & 38718 & 1 & 476 \\
\hline Standart Sapma & 287,70 & 605583,22 & 14693,27 & 138,19 & 208,88 & 15247,75 \\
\hline
\end{tabular}

2016 yılı İzmir ili genelindeki tüm hastanelerin genel ortalama hekim sayıs1 235,15, ortalama hemşire sayıs1 687118,22 , ortalama tescilli yatak sayıs1 11975,07, ortalama muayene sayıs1 108,67, ortalama taburcu hasta sayıs1 170,78 ve ortalama ameliyat sayısı 14743,00 olarak hesaplanmıştır.

\subsection{Etkinlik Analizi Sonuçları}

Hastanelerin 2014, 2015 ve 2016 yılları için girdi odaklı ölçeğe göre sabit getiri ve ölçeğe göre değiş̧ken getiri yaklaşımıyla yapılan etkinlik analizi sonuçları hesaplanmıştır. Daha sonra karar verme birimi olan hastanelerin ölçek etkinlikleri CCR ve BCC yaklaşımlarının oranlanması yoluyla hesaplanmıştır.

Tablo 7: Hastanelerin 2014, 2015, 2016 Y11 Etkinlik Analizi Sonuçları

\begin{tabular}{|c|c|c|c|c|c|c|c|c|c|}
\hline \multirow[t]{2}{*}{ Hastaneler } & \multicolumn{3}{|c|}{$\begin{array}{c}2014 \text { Yılı Hastanelerin } \\
\text { Etkinlik Analizi Sonuçları }\end{array}$} & \multicolumn{3}{|c|}{$\begin{array}{c}2015 \text { Yılı Hastanelerin } \\
\text { Etkinlik Analizi Sonuçları }\end{array}$} & \multicolumn{3}{|c|}{$\begin{array}{c}2016 \text { Yılı Hastanelerin } \\
\text { Etkinlik Analizi Sonuçları }\end{array}$} \\
\hline & CCR & BCC & CCR/BCC & CCR & BCC & CCR/BCC & CCR & BCC & CCR/BCC \\
\hline Aliağa DH & 0,99 & 1 & 0,99 & 1 & 1 & 1 & 1 & 1 & 1 \\
\hline Aliağa CİK DH & 0,264 & 1 & 0,264 & 0,428 & 1 & 0,428 & 0,285 & 1 & 0,285 \\
\hline Bayındır DH & 0,769 & 0,918 & 0,838 & 0,885 & 0,973 & 0,91 & 0,91 & 1 & 0,91 \\
\hline Bergama DH & 1 & 1 & 1 & 1 & 1 & 1 & 1 & 1 & 1 \\
\hline Bornova DH & 0,808 & 1 & 0,808 & 1 & 1 & 1 & 1 & 1 & 1 \\
\hline Buca DH & 0,783 & 0,967 & 0,809 & 0,79 & 1 & 0,79 & 0,727 & 1 & 0,727 \\
\hline Buca KDÇH & 1 & 1 & 1 & 1 & 1 & 1 & 1 & 1 & 1 \\
\hline Çeşme DH & 0,823 & 1 & 0,823 & 0,873 & 0,9 & 0,97 & 0,779 & 0,872 & 0,893 \\
\hline Çiğli DH & 1 & 1 & 1 & 1 & 1 & 1 & 0,518 & 1 & 0,518 \\
\hline Dikili DH & 0,67 & 1 & 0,67 & 0,936 & 1 & 0,936 & 0,828 & 1 & 0,828 \\
\hline Foça DH & 0,851 & 1 & 0,851 & 0,993 & 1 & 0,993 & 0,891 & 1 & 0,891 \\
\hline Gaziemir DH & 1 & 1 & 1 & 1 & 1 & 1 & 1 & 1 & 1 \\
\hline Katip Çelebi Ü. EAH & 0,601 & 0,786 & 0,764 & 0,758 & 1 & 0,758 & 0,47 & 1 & 0,47 \\
\hline Bozyaka EAH & 0,657 & 0,745 & 0,881 & 0,721 & 1 & 0,721 & 0,575 & 1 & 0,575 \\
\hline Karşıyaka DH & 0,854 & 1 & 0,854 & 0,755 & 1 & 0,755 & - & - & - \\
\hline Kemalpaşa DH & 1 & 1 & 1 & 1 & 1 & 1 & 0,916 & 0,971 & 0,943 \\
\hline Kiraz DH & 1 & 1 & 1 & 0,97 & $\mathbf{1}$ & 0,97 & 1 & 1 & 1 \\
\hline Dr. Behçet Uz ÇH & 0,498 & 0,499 & 0,999 & 0,738 & 0,74 & 0,998 & 0,558 & 0,644 & 0,866 \\
\hline Dr. Suat Seren Göğ. & 0,689 & 1 & 0,689 & 0,511 & 0,511 & 0,999 & 0,375 & 0,397 & 0,943 \\
\hline Alsancak DH & 0,626 & 0,628 & 0,997 & 0,716 & 1 & 0,716 & 0,637 & 0,696 & 0,914 \\
\hline Tepecik EAH & 0,958 & 1 & 0,958 & 0,906 & 1 & 0,906 & 0,568 & 1 & 0,568 \\
\hline Menemen DH & 1 & 1 & 1 & 1 & $\mathbf{1}$ & 1 & 0,839 & 1 & 0,839 \\
\hline Ödemiş DH & 0,896 & 0,897 & 0,999 & 0,943 & 0,943 & 0,999 & 0,934 & 1 & 0,934 \\
\hline Seferihisar DH & 0,709 & 0,909 & 0,78 & 0,695 & 0,799 & 0,87 & 0,729 & 0,833 & 0,874 \\
\hline Selçuk DH & 0,623 & 0,763 & 0,817 & 0,927 & 1 & 0,927 & 0,807 & 0,899 & 0,897 \\
\hline Tire DH & 0,987 & 1 & 0,987 & 1 & 1 & 1 & 0,946 & 1 & 0,946 \\
\hline Torbalı DH & 1 & 1 & 1 & 1 & 1 & 1 & 0,871 & 0,891 & 0,978 \\
\hline Urla DH & 0,725 & 0,758 & 0,957 & 0,892 & 0,909 & 0,981 & 0,775 & 0,781 & 0,993 \\
\hline
\end{tabular}

Tablo 7' de sunulan hastanelerin 2014, 2015, 2016 y1lı etkinlik analizi sonuçlarına göre 2014 y1lı İzmir ilinde faaliyet gösteren kamu hastanelerinin girdi odaklı ölçeğe göre sabit getiri (CCR) yaklaşımıyla yapılmış olan etkinlik analizi sonuçlarına göre 8 hastane (Bergama $\mathrm{DH}$, Buca KDÇH, Çiğli DH, Gaziemir DH, Kemalpaşa DH, Kiraz DH, Menemen DH, Torbalı DH) tam etkin olarak bulunmuştur. Etkinlik skoru en düşük hastaneler ise sirasıyla Aliağa CiK DH $(0,264)$, Dr. Behçet Uz ÇH $(0,498)$, Katip Çelebi Ü. EAH $(0,601)$ olarak bulunmuştur. Ölçeğe göre değişken getiri (BCC) 
yaklaşımıyla yapılmış olan etkinlik analizi sonuçlarına göre 18 hastane (Aliağa DH, Aliağa CíK DH, Bergama DH, Bornova DH, Buca KDÇH, Çeşme DH, Çiğli DH, Dikili DH, Foça DH, Gaziemir DH, Karşıyaka DH, Kemalpaşa DH, Kiraz DH, Dr. Suat Seren Göğ, Menemen DH, Tire DH, Torbalı DH) tam etkin olarak bulunmuştur. Etkinlik skoru en düşük hastane ise, Dr. Behçet Uz ÇH $(0,499)$, Alsancak DH $(0,628)$ olarak bulunmuştur. Söz konusu y1l için ölçek etkinliği skorlarına göre ölçek etkin kamu hastaneleri Bergama DH, Buca KDÇH, Çiğli DH, Gaziemir DH, Kemalpaşa DH, Kiraz $\mathrm{DH}$, Menemen DH, Torbalı DH olarak bulunmuştur. En düşük ölçek etkinliğine sahip hastane ise Aliağa CiK DH $(0,264)$, Dikili DH $(0,670)$ bulunmuştur. Girdi odaklı yaklaşımda hem CCR hem de BCC etkinlik skorları açısından tam etkin bulunan kamu hastaneleri Bergama DH, Buca KDÇH, Çiğli DH, Gaziemir DH, Kemalpaşa DH, Kiraz DH, Menemen DH, Torbalı DH olarak bulunmuştur.

2015 y1lı İzmir ilinde faaliyet gösteren kamu hastanelerinin girdi odaklı ölçeğe göre sabit getiri (CCR) yaklaşımıyla yapılmış olan etkinlik analizi sonuçlarına göre 10 hastane (Aliağa DH, Bergama DH, Bornova DH, Buca KDÇH, Çiğli DH, Gaziemir DH, Kemalpaşa DH, Menemen DH, Tire DH, Torbalı DH) tam etkin olarak bulunmuştur. Etkinlik skoru en düşük hastaneler ise sırasıyla Aliağa CİK DH $(0,428)$, Dr. Suat Seren Göğ. $(0,511)$, Seferihisar DH $(0,695)$ olarak bulunmuştur. Ölçeğe göre değişken getiri (BCC) yaklaşımıyla yapılmış olan etkinlik analizi sonuçlarına göre 21 hastane (Aliağa DH, Aliağa CíK DH, Bergama DH, Bornova DH, Buca DH, Buca KDÇH, Çiğli DH, Dikili DH, Foça DH, Gaziemir DH, Katip Çelebi Ü. DH, Bozyaka EAH, Karşıyaka DH, Kemalpaşa DH, Kiraz DH, Alsancak DH, Tepecik EAH, Menemen DH, Selçuk DH, Tire DH, Torbalı DH) tam etkin olarak bulunmuştur. Etkinlik skoru en düşük hastaneler ise sırasıyla Dr. Suat Seren Göğ. $(0,511)$, Dr.Behçet Uz ÇH $(0,740)$, Seferihisar DH $(0,799)$ olarak bulunmuştur. Ölçek etkinliği skorlarına göre ölçek etkin kamu hastaneleri Aliağa DH, Bergama DH, Bornova DH, Buca KDÇH, Çiğli DH, Gaziemir DH, Menemen DH, Kemalpaşa DH, Tire DH, Torbalı DH olarak bulunmuştur. En düşük ölçek etkinliğine sahip hastaneler ise sırasıyla Aliağa CİK DH $(0,428)$ Alsancak DH $(0,716)$, Bozyaka EAH $(0,721)$ olarak bulunmuştur. 2015 yılı için girdi odaklı yaklaşımda hem CCR hem de BCC etkinlik skorları açısından tam etkin bulunan kamu hastaneleri Aliağa DH, Bergama DH, Bornova DH, Buca KDÇH, Çiğli DH, Gaziemir DH, Kemalpaşa DH, Menemen DH, Tire DH, Torbalı DH olarak bulunmuştur.

2016 y1lı İzmir ilinde faaliyet gösteren kamu hastanelerinin girdi odaklı ölçeğe göre sabit getiri (CCR) yaklaşımıyla yapılmış olan etkinlik analizi sonuçlarına göre 6 hastane (Aliağa DH, Bergama DH, Bornova DH, Buca KDÇH, Gaziemir DH, Kiraz DH) tam etkin olarak bulunmuştur. Etkinlik skoru en düşük hastaneler ise sirasıyla Aliağa CiK DH $(0,285)$, Dr. Suat Seren Göğ. $(0,375)$, Katip Çelebi Ü. EAH $(0,470)$, Çiğli DH, $(0,518)$ olarak bulunmuştur. Ölçeğe göre değişken getiri (BCC) yaklaşımıyla yapılmış olan etkinlik analizi sonuçlarına göre 21 hastane (Aliağa DH, Aliağa CíK DH, Bayındır DH, Bergama DH, Bornova DH, Buca DH, Buca KDÇH, Çiğli DH, Dikili DH, Foça DH, Gaziemir DH, Katip Çelebi Ü. EAH, Bozyaka EAH, Kiraz DH, Tepecik EAH, Menemen DH, Ödemiş DH, Tire DH) tam etkin olarak bulunmuştur. Etkinlik skoru en düşük hastane ise Dr. Suat Seren Göğ. $(0,397)$, Dr. Behçet Uz ÇH $(0,644)$, Alsancak DH $(0,696)$ olarak bulunmuştur. 2016 yılı ölçek etkinliği skorlarına göre ölçek etkin kamu hastaneleri ise Aliağa DH, Bergama DH, Bornova DH, Buca KDÇH, Gaziemir DH, Kiraz DH olarak bulunmuştur. En düşük ölçek etkinliğine sahip hastane ise Aliağa CİK DH (0,285), Katip Çelebi Ü. EAH $(0,470)$, Çiğli DH $(0,518)$, Tepecik EAH $(0,568)$ olarak bulunmuştur. Hem CCR hem de BCC etkinlik skorları açısından tam etkin bulunan kamu hastaneleri Aliağa DH, Bergama DH, Bornova DH, Buca KDÇH, Gaziemir DH, Kiraz DH olarak bulunmuştur.

\subsection{Etkin Olmayan Hastaneler İçin İyileştirme Önerileri}

2014, 2015 ve 2016 yılları için yapılan analizler sonucunda etkin olmayan hastanelerin etkin hale gelebilmeleri için hekim sayısı, hemşire sayısı ve yatak sayısının gerektiği kadar azaltılması muayene sayısı taburcu olan hasta sayısı ve ameliyat sayısının gerektiği kadar artırılması önerilir. Yapılan analizler sonucunda hastanelerin etkin hale gelmesi için aşağıdaki düzenlemeleri yapmaları önerilmektedir. 
Tablo 8: 2014 Yılı Girdi Odaklı CCR Yaklaşımında Etkin Olmayan Hastaneler İçin İyileştirme Önerileri

\begin{tabular}{|c|c|c|c|c|c|c|}
\hline Hastaneler & $\begin{array}{c}\text { Hekim } \\
\text { Sayısı } \\
\end{array}$ & $\begin{array}{c}\text { Hemşire } \\
\text { Sayısı }\end{array}$ & $\begin{array}{c}\text { Tescilli Yatak } \\
\text { Sayısı }\end{array}$ & $\begin{array}{c}\text { Muayene } \\
\text { Sayısı }\end{array}$ & $\begin{array}{c}\text { Taburcu Olan } \\
\text { Hasta Sayısı } \\
\end{array}$ & $\begin{array}{c}\text { Ameliyat } \\
\text { Sayısı }\end{array}$ \\
\hline Aliağa DH & 0 & 11,234 & 6,209 & 0 & 0 & 0 \\
\hline Aliağa CİK DH & 0 & 0 & 3,086 & 0 & 329,303 & 585,839 \\
\hline Bayındır DH & 0 & 3,219 & 0 & 0 & 0 & 3582,494 \\
\hline Bornova DH & 0 & 0 & 5,713 & 0 & 1855,804 & 0 \\
\hline Buca DH & 0 & 39,269 & 65,327 & 0 & 0 & 1493,691 \\
\hline Çeşme DH & 0 & 2,41 & 0 & 0 & 865,207 & 888,611 \\
\hline Çiğli DH & 0 & 0 & 0 & 0 & 0 & 0 \\
\hline Dikili DH & 0 & 0,912 & 0 & 0 & 37,207 & 78,902 \\
\hline Foça DH & 0 & 4,315 & 0 & 0 & 163,063 & 0 \\
\hline Gaziemir DH & 0 & 0 & 0 & 0 & 0 & 0 \\
\hline Katip Çelebi Ü. EAH & 0 & 111,046 & 79,955 & 456046,1 & 0 & 0 \\
\hline Bozyaka EAH & 0 & 101,983 & 132,044 & 95142,28 & 0 & 0 \\
\hline Karşıyaka DH & 0 & 47,866 & 0 & 0 & 0 & 0 \\
\hline Dr. Behçet Uz ÇH & 0 & 51,373 & 77,002 & 0 & 0 & 4137,565 \\
\hline Dr. Suat Seren Göğ. & 0 & 0 & 51,193 & 0 & 0 & 0 \\
\hline Alsancak DH & 0 & 64,9 & 41,417 & 0 & 0 & 11161,84 \\
\hline Tepecik EAH & 0 & 199,772 & 167,821 & 1210160 & 0 & 0 \\
\hline Ödemiş DH & 0 & 12,417 & 56,088 & 0 & 0 & 3136,351 \\
\hline Seferihisar DH & 0 & 0 & 14,128 & 0 & 0 & 0 \\
\hline Selçuk DH & 0 & 0 & 0 & 0 & 0 & 90,454 \\
\hline Tire DH & 0 & 22,897 & 43,434 & 125187,9 & 0 & 0 \\
\hline Urla DH & 0 & 13,346 & 0 & 0 & 0 & 0 \\
\hline
\end{tabular}

Tablo 8'de 2014 yılı için girdi odaklı CCR Yaklaşımında Etkin Olmayan Hastaneler İçin İyileştirme Önerileri sunulmuştur Aliağa DH için hemşire sayısının 11,234 ve yatak sayısının 6,209 azaltılması gerekmektedir. Aliağa CiKDH için yatak sayısının 3,086 azaltılması taburcu olan hasta sayısının 329,303 ve ameliyat sayısının 585,839 artırılması gerekmektedir. Bayındır DH için hemşire sayısının 3,219azaltılması ve ameliyat sayısının 3582,494 artırılması gerekmektedir.

Tablo 9: 2015 Yılı Girdi Odaklı CCR Yaklaşımında Etkin Olmayan Hastaneler İçin İyileştirme Önerileri

\begin{tabular}{|c|c|c|c|c|c|c|}
\hline Hastaneler & $\begin{array}{c}\text { Hekim } \\
\text { Sayısı }\end{array}$ & $\begin{array}{c}\text { Hemşire } \\
\text { Sayısı } \\
\end{array}$ & $\begin{array}{c}\text { Tescilli Yatak } \\
\text { Sayısı }\end{array}$ & $\begin{array}{c}\text { Muayene } \\
\text { Sayısı }\end{array}$ & $\begin{array}{c}\text { Taburcu Olan } \\
\text { Hasta Sayısı }\end{array}$ & $\begin{array}{c}\text { Ameliyat } \\
\text { Sayısı }\end{array}$ \\
\hline Aliağa CİK DH & 0,335 & 0 & 4,446 & 144,79 & 531,298 & 0 \\
\hline Bayındır DH & 0 & 1,491 & 3,941 & 0 & 0 & 2348,87 \\
\hline Buca DH & 0 & 18,51 & 40,084 & 0 & 0 & 0 \\
\hline Çeşme DH & 0 & 0 & 11,928 & 0 & 725,378 & 1903,13 \\
\hline Dikili DH & 0 & 8,836 & 3,688 & 0 & 0 & 1903,6 \\
\hline Foça DH & 0 & 9,733 & 7,804 & 0 & 295,223 & 1847,61 \\
\hline Katip Çelebi Ü. EAH & 0 & 62,628 & 11,645 & 369105 & 0 & 0 \\
\hline Bozyaka EAH & 0 & 60,986 & 31,319 & 200014 & 0 & 0 \\
\hline Karşıyaka DH & 0 & 37,205 & 0 & 0 & 0 & 0 \\
\hline Kiraz DH & 0 & 12,985 & 8,534 & 0 & 0 & 2021,77 \\
\hline Dr. Behçet Uz ÇH & 0 & 103,817 & 48,098 & 0 & 0 & 959,443 \\
\hline Dr. Suat Seren Göğ. & 0 & 24,161 & 12,557 & 6571,05 & 0 & 0 \\
\hline Alsancak DH & 0 & 0 & 47,09 & 0 & 0 & 2198,9 \\
\hline Tepecik EAH & 0 & 148,393 & 0 & 881199 & 0 & 0 \\
\hline Ödemiş DH & 0 & 18,334 & 14,779 & 0 & 0 & 2753,58 \\
\hline Seferihisar DH & 0 & 0 & 5,978 & 0 & 0 & 0 \\
\hline Selçuk DH & 0 & 0 & 4,32 & 0 & 0 & 0 \\
\hline Urla DH & 0 & 6,133 & 22,235 & 0 & 0 & 2301,59 \\
\hline
\end{tabular}

Tablo 9'da 2015 y1lı için girdi odaklı CCR Yaklaşımında Etkin Olmayan Hastaneler İçin İyileştirme Önerileri sunulmuştur. Aliağa CIK DH için hekim sayısının 0,335, yatak sayısının 4,446 azaltılmas1, muayene sayısının 144,79 ve taburcu olan hasta sayısının 531,298 artırılmas1 gerekmektedir. Bayındır DH için hemşire sayısının 1,491 yatak sayısının 3,941 azaltılması ve ameliyat sayısının 2348,87 artırılması gerekmektedir. Buca DH için hemşire sayısının 18,51 yatak sayısının 40,084 azaltılmas1 gerekmektedir. 
Tablo 10: 2016 Yılı Girdi Odaklı CCR Yaklaşımında Etkin Olmayan Hastaneler İçin İyileştirme Önerileri

\begin{tabular}{|c|c|c|c|c|c|c|}
\hline Hastaneler & $\begin{array}{c}\text { Hekim } \\
\text { Sayısı }\end{array}$ & $\begin{array}{c}\text { Hemşire } \\
\text { Sayısı }\end{array}$ & $\begin{array}{c}\text { Tescilli Yatak } \\
\text { Sayısı } \\
\end{array}$ & $\begin{array}{c}\text { Muayene } \\
\text { Sayısı } \\
\end{array}$ & $\begin{array}{c}\text { Taburcu Olan } \\
\text { Hasta Sayısı }\end{array}$ & $\begin{array}{c}\text { Ameliyat } \\
\text { Sayısı }\end{array}$ \\
\hline Aliağa CíK DH & 0 & 1,3 & 0 & 0 & 181,079 & 0 \\
\hline Bayındır DH & 0 & 0 & 3,302 & 0 & 0 & 1556,46 \\
\hline Buca DH & 0 & 0 & 71,773 & 0 & 0 & 0 \\
\hline Çeşme DH & 0 & 4,937 & 0 & 0 & 624,774 & 0 \\
\hline Çiğli DH & 0 & 0 & 42,359 & 24339,7 & 0 & 0 \\
\hline Dikili DH & 0 & 15,449 & 0 & 0 & 123,117 & 0 \\
\hline Foça DH & 0 & 20,113 & 0 & 0 & 0 & 0 \\
\hline Katip Çelebi Ü. EAH & 0 & 0 & 41,734 & 0 & 0 & 0 \\
\hline Bozyaka EAH & 0 & 31,317 & 73,009 & 166751 & 0 & 0 \\
\hline Kemalpaşa DH & 0 & 19,361 & 0 & 0 & 662,898 & 0 \\
\hline Dr. Behçet Uz ÇH & 0 & 27,305 & 32,079 & 0 & 0 & 0 \\
\hline Dr. Suat Seren Göğ. & 0 & 0 & 20,307 & 0 & 0 & 0 \\
\hline Alsancak DH & 3,358 & 0 & 35,295 & 2720,09 & 213,11 & 0 \\
\hline Tepecik EAH & 0 & 0 & 22,736 & 463949 & 0 & 0 \\
\hline Menemen DH & 0 & 0 & 19,413 & 0 & 0 & 0 \\
\hline Ödemiş DH & 0 & 0 & 31,615 & 0 & 0 & 1141,56 \\
\hline Seferihisar DH & 0 & 7,466 & 0 & 0 & 0 & 0 \\
\hline Selçuk DH & 0 & 0 & 0 & 0 & 0 & 1356,68 \\
\hline Tire DH & 0 & 24,383 & 93,915 & 0 & 0 & 0 \\
\hline Torbalı DH & 0 & 0 & 6,117 & 17779,6 & 0 & 0 \\
\hline Urla DH & 0 & 0 & 12,233 & 0 & 0 & 1752,25 \\
\hline
\end{tabular}

Tablo 10'da 2016 y1lı için girdi odaklı CCR Yaklaşımında Etkin Olmayan Hastaneler İçin İyileştirme Önerileri sunulmuştur. Aliağa CIK DH için hemşire sayısının 1,3 azaltılması ve taburcu olan hasta sayısının 181,079 artırılması gerekmektedir. Bayındır DH için yatak sayısının3,302 azaltılması ve ameliyat sayısının 1556,46 artırılması gerekmektedir. Buca DH için yatak sayısının 71,773 azaltılmas1 gerekmektedir.

\subsection{Süper Etkinlik Analizi Sonuçları}

Etkin olan karar verme birimlerinin tespitinden sonra bu birimlerin de kendi arasinda bir sıralamasının yapılması için süper etkinlik skorlarından yararlanılır.

Tablo 11: Hastanelerin 2014, 2015, 2016 Y1lı Süper Etkinlik Analizi Sonuçları

\begin{tabular}{|c|c|c|c|c|c|c|}
\hline \multirow[t]{2}{*}{ Hastaneler } & \multicolumn{2}{|c|}{$\begin{array}{l}2014 \text { Yılı Hastanelerin } \\
\text { Süper Etkinlik Analizi }\end{array}$} & \multicolumn{2}{|c|}{$\begin{array}{l}2015 \text { Yılı Hastanelerin } \\
\text { Süper Etkinlik Analizi }\end{array}$} & \multicolumn{2}{|c|}{$\begin{array}{l}2016 \text { Yılı Hastanelerin } \\
\text { Süper Etkinlik Analizi }\end{array}$} \\
\hline & CCR & BCC & CCR & BCC & CCR & BCC \\
\hline Aliağa DH & 0,99 & 1,044 & 1,414 & 1,48 & 1,66 & 1,665 \\
\hline Aliağa CİK DH & 0,264 & 2,154 & 0,428 & 2,366 & 0,285 & 1,662 \\
\hline Bayındır DH & 0,769 & 0,918 & 0,885 & 0,973 & 0,91 & 1,013 \\
\hline Bergama DH & 1,077 & 1,092 & 1,011 & 1,138 & 1,049 & 1,096 \\
\hline Bornova DH & 0,807 & 1,511 & 1,358 & 1,434 & 1,777 & 2,231 \\
\hline Buca DH & 0,783 & 0,967 & 0,79 & 1,04 & 0,727 & 1,125 \\
\hline Buca KDÇH & 1,952 & 2,043 & 1,808 & 1,849 & 2,085 & 2,453 \\
\hline Çeşme DH & 0,823 & 1,063 & 0,873 & 0,9 & 0,779 & 0,872 \\
\hline Çiğli DH & 1,542 & 1,63 & 1,52 & 1,639 & 0,518 & 1,131 \\
\hline Dikili DH & 0,67 & 1,023 & 0,936 & 1,143 & 0,828 & 1,075 \\
\hline Foça DH & 0,851 & 1,18 & 0,993 & 1,07 & 0,891 & 1,069 \\
\hline Gaziemir DH & 1,721 & 2,618 & 1,137 & 1,376 & 1,566 & 2,135 \\
\hline Katip Çelebi Ü. EAH & 0,601 & 0,786 & 0,758 & 1,03 & 0,47 & 1 \\
\hline Bozyaka EAH & 0,656 & 0,745 & 0,721 & 1,157 & 0,575 & 1,205 \\
\hline Karşıyaka DH & 0,854 & 1,461 & 0,755 & 1,846 & - & - \\
\hline Kemalpaşa DH & 1,062 & 1,067 & 1,063 & 1,072 & 0,916 & 0,971 \\
\hline Kiraz DH & 1,087 & 1,303 & 0,97 & $\mathbf{1 , 0 3 2}$ & 1,048 & 1,437 \\
\hline Dr. Behçet Uz ÇH & 0,498 & 0,499 & 0,738 & 0,74 & 0,559 & 0,644 \\
\hline Dr. Suat Seren Göğ. & 0,689 & 1,075 & 0,511 & 0,511 & 0,375 & 0,397 \\
\hline Alsancak DH & 0,626 & 0,628 & 0,716 & 1,158 & 0,637 & 0,696 \\
\hline Tepecik EAH & 0,958 & 1 & 0,905 & 1 & 0,568 & 1 \\
\hline Menemen DH & 1,036 & 1,175 & 1,032 & 1,206 & 0,839 & $\mathbf{1 , 0 3}$ \\
\hline
\end{tabular}


Tablo 11 (Devamı): Hastanelerin 2014, 2015, 2016 Yılı Süper Etkinlik Analizi Sonuçları

\begin{tabular}{lcccccc}
\hline Hastaneler & $\begin{array}{l}\text { 2014 Yll Hastanelerin } \\
\text { Süper Etkinlik Analizi }\end{array}$ & \multicolumn{2}{c}{$\begin{array}{c}\text { 2015 Yll Hastanelerin } \\
\text { Süper Etkinlik Analizi }\end{array}$} & \multicolumn{2}{c}{$\begin{array}{c}\text { 2016 Yll Hastanelerin } \\
\text { Süper Etkinlik Analizi }\end{array}$} \\
\hline Ödemiş DH & 0,896 & 0,897 & 0,943 & 0,943 & 0,934 & $\mathbf{1 , 0 7 7}$ \\
\hline Seferihisar DH & 0,709 & 0,909 & 0,695 & 0,799 & 0,728 & 0,833 \\
\hline Selçuk DH & 0,623 & 0,763 & 0,927 & $\mathbf{1 , 0 5 3}$ & 0,807 & 0,899 \\
\hline Tire DH & 0,987 & $\mathbf{1 , 0 0 1}$ & $\mathbf{1 , 0 3 9}$ & $\mathbf{1 , 0 5 4}$ & 0,946 & $\mathbf{1 , 0 8 2}$ \\
\hline Torbalı DH & $\mathbf{1 , 0 1}$ & $\mathbf{1 , 1 3 8}$ & $\mathbf{1 , 0 2 5}$ & $\mathbf{1 , 0 2 8}$ & 0,871 & 0,891 \\
\hline Urla DH & 0,725 & 0,758 & 0,892 & 0,909 & 0,775 & 0,781 \\
\hline
\end{tabular}

Tablo 11'de hastanelerin 2014, 2015 ve 2016 yılları için süper etkinlik analizi gösterilmiştir. 2014 yılı kamu hastanelerinin girdi odaklı ölçeğe göre sabit getiri (CCR) yaklaşımıyla yapılmış olan süper etkinlik analizi sonuçlarına göre etkinlik skoru en yüksek hastane Buca $\operatorname{KDÇH~}(1,952)$, Gaziemir DH (1,721), Çiğli DH (1,542), Kiraz DH $(1,087)$, Bergama DH $(1,077)$, Kemalpaşa DH $(1,062)$, Menemen DH $(1,036)$, Torbalı DH $(1,010)$ olarak bulunmuştur. 2014 y1lı kamu hastanelerinin girdi odaklı ölçeğe göre değişken getiri (BCC) yaklaşımıyla yapılmış olan süper etkinlik analizi sonuçlarına göre Gaziemir DH (2,618), Aliağa CiK DH $(2,154)$, Buca KDÇH $(2,043)$, Çiğli DH $(1,630)$, Bornova DH $(1,511)$, Karşıyaka DH $(1,461)$, Kiraz DH $(1,303)$, Foça DH $(1,180)$, Menemen DH $(1,175)$, Torbalı DH $(1,138)$, Bergama DH $(1,092)$, Dr. Suat Seren Göğ. $(1,075)$, Kemalpaşa DH $(1,067)$, Çeşme DH $(1,063)$, Aliağa DH $(1,044)$, Dikili DH $(1,023)$, Tire DH $(1,001)$, Tepecik EAH $(1,000)$ tam etkin olarak bulunmuştur.

2015 yılı kamu hastanelerinin girdi odaklı ölçeğe göre sabit getiri (CCR) yaklaşımıyla yapılmış olan süper etkinlik analizi sonuçlarına göre etkinlik skoru en yüksek hastane Buca KDÇH $(1,808)$, Çĭgli DH $(1,520)$, Aliağa DH $(1,414)$, Bornova DH $(1,358)$, Gaziemir DH $(1,137)$, Kemalpaşa DH (1,063), Tire DH (1,039), Menemen DH (1,032), Torbalı DH $(1,025)$, Bergama DH $(1,011)$ olarak bulunmuştur. 2015 yılı kamu hastanelerinin girdi odaklı ölçeğe göre değişken getiri (BCC) yaklaşımıyla yapılmış olan süper etkinlik analizi sonuçlarına göre etkinlik skoru en yüksek hastane Aliağa CiK DH (2,366), Buca KDÇH $(1,849)$, Karşıyaka DH $(1,846)$, Çiğli DH $(1,639)$, Aliağa DH $(1,480)$, Bornova DH $(1,434)$, Gaziemir DH $(1,376)$, Menemen DH $(1,206)$, Alsancak DH $(1,158)$, Bozyaka EAH (1,157), Dikili DH (1,143), Bergama DH $(1,138)$, Kemalpaşa DH $(1,072)$, Foça DH $(1,070)$, Tire DH $(1,054)$, Selçuk DH $(1,053)$, Buca DH $(1,040)$, Kiraz DH $(1,032)$, Katip Çelebi Ü.EAH (1,030), Torbalı DH $(1,028)$, Tepecik EAH $(1,000)$ olarak bulunmuştur.

2016 yılı kamu hastanelerinin girdi odaklı ölçeğe göre sabit getiri (CCR) yaklaşımıyla yapılmış olan süper etkinlik analizi sonuçlarına göre etkinlik skoru en yüksek hastane Buca KDÇH $(2,085)$, Bornova DH $(1,777)$, Aliağa DH $(1,660)$, Gaziemir DH $(1,566)$, Bergama DH $(1,049)$ Kiraz DH $(1,048)$ olarak bulunmuştur. 2016 yılı kamu hastanelerinin girdi odaklı ölçeğe göre değişken getiri (BCC) yaklaşımıyla yapılmış olan süper etkinlik analizi sonuçlarına göre etkinlik skoru en yüksek hastane Buca KDÇH $(2,453)$, Bornova DH $(2,231)$, Gaziemir DH $(2,135)$, Aliağa DH $(1,665)$, Aliağa CíK DH $(1,662)$, Kiraz DH $(1,437)$, Bozyaka EAH $(1,205)$, Çiğli DH $(1,131)$, Buca DH $(1,125)$, Bergama DH $(1,096)$, Tire DH $(1,082)$, Ödemiş DH $(1,077)$, Dikili DH $(1,075)$, Foça DH $(1,069)$, Menemen DH $(1,030)$, Bayındır DH $(1,013)$, Katip Çelebi Ü. EAH $(1,000)$, Tepecik EAH $(1,000)$ olarak bulunmuştur.

\section{SONUÇ VE ÖNERILLER}

Maliyetlerin ve sağlık harcamalarının artışı kullanılan kaynakların etkili ve verimli şekilde değerlendirilip değerlendirilemediği sorusunu gündeme getirmiştir. Sağlıkta dönüşüm programının başlatılmasıyla birlikte kamu sağlık kuruluşlarının da özel sektörde olduğu gibi performansının izlenmesi ve hizmet birimlerinin bu performans doğrultusunda sınıflara ayrılması sağlanmıştır. Kar amacı gütmeyen kamu hastaneleri için aynı hizmeti daha düşük maliyetlerle sunmak, dolayısıyla daha az girdi kullanımı ile daha çok çıktı elde etmek önemli bir etkinlik amacı oluşturmuştur.

Kamu hastanelerinin etkinliğini değerlendirmek adına Sağlık Bakanlığı verimlilik karne uygulaması kapsamında gösterge kartları hazırlamıştır. Gösterge kartlarında hastanelerin sağlık hizmetleri yönetimi, mali hizmetler yönetimi ve idari hizmetler yönetimine ilişkin çeşitli oran ve standartlar belirlenmiştir. Etkinlik ölçümünde mevcut durum ile standart durumun kıyaslaması yapılabileceği gibi, etkinliği değerlendirilen birimlerin kendi aralarında kıyaslamaya gidilmesi de 
mümkündür. Bu çalışma kapsamında da İzmir ilinde faaliyet gösteren kamu hastanelerinin kullanmış olduğu girdiler ve bu girdilerle elde ettiği çıktılar açısından göreceli mukayesesine dayalı olarak etkinliklerinin ölçümü amaçlanmıştır. Veri zarflama analizi yöntemi ile 2014, 2015 ve 2016 yıllarına ait etkinlik değerleri girdi odaklı yaklaşımla ölçeğe göre sabit ve ölçeğe göre değişken getiri varsayımlarına dayalı olarak hesaplanmıştır.

Çalışmada girdi değişkeni olarak kullanılan hekim ve yatak sayısı 2014 yılından 2015 yılına gelindiğinde azaldığ 12016 yılında ise arttı̆̆ 1 görülmektedir. Diğer girdi değişkeni olan hemşire sayısı ise ortalama olarak her yıl artış göstermiştir. Çıktı değişkeni olarak kullanılan taburcu edilen hasta sayısı ve ameliyat sayısı 2015 yılında bir önceki yıla göre azalırken 2016 yılında artış göstermiştir. Diğer çıktı değişkeni olan muayene edilen hasta sayısı ise yıllar itibariyle artış göstermiştir.

Hastanelerin hizmet sunumunda etkin olabilmeleri için aynı miktar çıktıyı elde ederken girdi sayısını azaltması ya da aynı miktar girdi ile daha fazla çıktı elde etmesi gerekmektedir. Çalışma kapsamında kullanılan girdi değişkenlerinin hekim sayısı, hemşire sayısı ve hastane yatağ1 sayısı olduğu göz önünde bulundurulduğunda etkinlik artışı için yönetsel açıdan çıktı miktarına odaklanılması daha rasyonel olacaktır.

2014 yılı için yapılan analiz sonuçlarına göre toplam 28 hastanenin sadece 7 tanesi hem ölçeğe göre sabit getiri varsayımında hem de ölçeğe göre değişken getiri varsayımında etkin sonuçlar vererek ölçek etkin bulunmuştur. 2014 yılı hesaplamalarında etkin olmayan hastanelerin etkin olabilmeleri için genel olarak girdi değişkenlerinde hemşire ve yatak sayılarını azaltmaları ya da çıktı değişkenlerinde taburcu edilen hasta sayısı veya ameliyat sayısını artırmaları önerilmektedir. Taburcu olan hasta sayıs1 açısından Bornova Türkan Özilhan Devlet Hastanesi en fazla iyileştirme yapması gereken birim olurken, muayene sayısı açısından Tire Devlet Hastanesi en fazla iyileştirmeye ihtiyaç duyan kurum olmuştur.

2015 yılında yapılan tüm etkinlik analizlerinde etkin bulunan toplam hastane sayıs1 9 olmuştur. Bu durum 2015 yılı etkinlik ortalamalarının da bir önceki yıla göre daha yüksek olmasını sağlamıştır. 2015 yılı için süper etkinlik sonuçlarına bakıldığında ise Çiğli Devlet Hastanesi'nin diğer etkin hastaneler arasında ilk sırada olduğu sonucuna varılmaktadır. Etkin olmayan hastanelerden Çeşme, Foça ve Aliağa C.İ.K Devlet hastanelerinin etkin olabilmek için taburcu ettikleri hasta ve ameliyat sayısını artırmaları gerekmektedir.

2016 yılında tüm analizlerde etkin bulunan hastane sayısı 6 olarak gerçekleşmiştir. Bu yılın genel etkinlik ortalamaları bir önceki yıla göre azalış göstermektedir. Süper etkinlik sonuçlarına göre ise Kiraz ve Bornova Devlet hastaneleri bu etkin hastaneler içerisinde çıktı odaklı yaklaşıma göre ilk iki sırada yer almaktadır. Etkin olmayan hastaneler içerisinde en ciddi iyileştirmelere gereksinim duyan hastaneler ise Çeşme ve Kemal Paşa Devlet hastaneleri olmuştur.

İncelenen y1llar itibariyle gerçekleştirilmiş olan tüm etkinlik ölçümlerinde 2015 yılında 2016 yılına göre artış yaşanırken 2016 yılında bir önceki yıla göre azalış meydana gelmiştir. Bergama Devlet Hastanesi, Buca Kadın Doğum Hastanesi ve Gaziemir Devlet Hastanesi istikrarlı bir etkinlik performansı göstererek incelenen tüm yıllarda yapılan tüm analizler için etkin olarak bulunma başarısını göstermiş̧tir.

İzmir ilinde yer alan devlet hastanelerinin etkinliğini değerlendiren bu çalışmanın daha uzun yılları kapsayacak şekilde yeniden yürütülmesi ile ileriye yönelik projeksiyonların yapılabileceği, aynı zamanda yöneticilerin olası etkinlik düşüşlerinin önüne bugünden geçebilmesi için bir firsat oluşturulabileceği düşünülmektedir.

Yürütülen teknik analizler neticesinde etkinliğe erişebilmek adına bazı girdilerin azaltılması bazı çıktıların ise artırılması önerilmektedir. Ancak sağlık sektörünün doğasına özgü bazı özellikler onu diğer sektörlerden ayırmaktadır. Türkiye hekim, hemşire ve diğer sağlık personeli açı̆̆ı bulunan bir ülkedir. Mevcut sınırlı kaynaklarla en etkili ve verimli sağlık hizmetlerinin sunulabilmesi amaçlanmaktadır. Devlet hastanelerinin etkinlik sınırına yaklaştırılabilmesi için sunulan hizmetin temel çıktıları olarak kabul edilen ameliyat sayısı, taburcu edilen hasta sayısı, poliklinik sayısı gibi değişkenlere sadece nicelik bazında değil aynı zamanda nitelik bazında da bakılması önem arz etmektedir. 
Etik Beyanı: Bu çalışmada "Etik Kurul” izni gerektiren bir yöntem kullanılmamıştır.

Yazar Katkı Beyanı:1. Yazarın katkı oranı \%50, 2. Yazarın katkı oranı ise \%50'dir.

Çıkar Beyanı: Yazarlar arasında çıkar çatışması yoktur.

Ethic Statement: In this study, no method requiring the permission of the "Ethics Committee" was used.

Author Contributions Statement: 1st author's contribution rate 50\%, 2nd author's contribution rate $50 \%$.

Conflict of Interest: There is no conflict of interest among the authors.

\section{KAYNAKCA}

Bakırcı, F. (2006). Sektörel bazda bir etkinlik ölçümü: VZA ile bir analiz. Atatürk Üniversitesi İktisadi ve İdari Bilimler Dergisi, 20(2), 199-217. https://dergipark.org.tr/tr/download/article-file/30113

Banker, R. D. (1992). Estimation of returns to scale using data envelopment analysis. European Journal of Operational Research, 62, 74-84. https://doi.org/10.1016/0377-2217(92)90178-C

Başkaya, Z., \& Akar, C. (2005). Sigorta şirketlerinin satış performanslarının veri zarflama analizi yöntemiyle belirlenmesi. Muğla Üniversitesi Sosyal Bilimler Enstitüsü Dergisi (ILLKE) Güz, (15), 37-51. https://dergipark.org.tr/tr/download/article-file/217334

Bayraktutan, Y., \& Pehlivanoğlu, F. (2012). Sağl1k işletmelerinde etkinlik analizi: Kocaeli örneği. Kocaeli Üniversitesi Sosyal Bilimler Enstitüsü Dergisi 23, 127-162. https://dergipark.org.tr/tr/download/article-file/251885

Baysal, K. (2010). İsletmelerde etkinlik ve verimlilik ölçüm yöntemleri: Bir yazıllm önerisi (Yayın No. 271365) [Yüksek Lisans Tezi, Gazi Üniversitesi] Yüksek Öğretim Kurumu Tez Merkezi. https://tez.yok.gov.tr/UlusalTezMerkezi/tezDetay.jsp?id=dEGJ3agjfwvcM8EiTzihBw\&no=ef3 Hq_LEINRqYjApZ_quuw

Ben-Arieh, D., \& Gullipalli, D. K. (2012). Data envelopment analysis of clinics with sparse data: Fuzzy clustering approach. Computers \& Industrial Engineering, 63(1), 13-21. http://doi.10.1016/j.cie.2012.01.009

Bülbül, S., \& Akhisar, İ. (2004). Türk sigorta şirketlerinin etkinliğinin veri zarflama analizi ile araştırılması. M.Ü. Bankacılı ve Sigortacılı Yüksek Okulu. https://dergipark.org.tr/tr/download/article-file/287381

Charnes, A., Cooper, W. W., \& Rhodes, E. (1981). Evaluating program and managerail efficiencey: An application of data envolopment analysis to program follow through. Management Science, 27(6), 668-697. https://www.jstor.org/stable/2631155

Cooper, W. W., Seiford, L. M., \& Tone, K. (2007). Data envelopment analysis a comprehensive text with models, applications. References and DEA-Solver Software.

Cooper, W. W., Seiford, L. M., \& Zhu, J. (2011). Handbook on data envelopment analysis (2nd ed.). Springer.

Dilts, D. M., Zell, A., \& Orwoll, E. (2015). A novel approach to measuring efficiency of scientific research projects: Data envelopment analysis. Clinical and Translational Science Journal, 8(5), 495-501. https://doi.10.1111/cts.12303

Erkorol, G. (2009). Veri zarflama analizi ile etkinlik ölçümü ve sektörel bir uygulama (Yayın No. 257491) [Yüksek Lisans Tezi, Dokuz Eylül Üniversitesi] Yüksek Öğretim Kurumu Tez Merkezi.

https://tez.yok.gov.tr/UlusalTezMerkezi/tezDetay.jsp?id=ndU0OV0VPWDEz3ooXBp4cg\&no= luj5KsqChSfnvakoGWwJJQ

Farzianpour, F., Hosseini, S., Amali, T., Hosseini, S., \& Hosseini, S. S. (2012). The evaluation of relative efficiency of teaching hospitals. American Journal of Applied Sciences, 9(3), 392. https://doi.org/10.3844/ajassp.2012.392.398 
Kumar, S., \& Gulati, R. (2008). An examination of technical, pure technical, and scale efficiencies in Indian public sector banks using data envelopment analysis. Eurasian Journal of Business and Economics, 1(2), 33-69. https://www.ejbe.org/EJBE2008Vol01No02p33KUMAR-GULATI.pdf

Levent, P. (2010). İzmir ili devlet ve üniversite hastanelerinde göreceli etkinlik analizi: Veri zarflama analizine dayalı bir uygulama (Yayın No. 257491) [Yüksek Lisans Tezi, Ege Üniversitesi] Yüksek Öğretim $\quad$ Kurumu $\quad$ Tez https://tez.yok.gov.tr/UlusalTezMerkezi/tezDetay.jsp?id=Mz6pbTFjnydeaYujvr31w\&no=QAMG8hM580GcUoLYb-MuuA

Li, G., Hui, L., \& Songtao, W. (2009). A study on distribution of medical resources in city downtown hospitals based on DEA method. International Forum on Information Technology and Application, 3, 371-374 https://doi.org/10.1177/0972063420908372

Liu, J. S., Lu, L. Y. Y., Lu, W. M., \& Lin, B. J. Y. (2013). Data envelopment analysis 1978-2010: A citation-based literatüre survey. OMEGA, 41(1), 3-15. http://10.1016/ j.omega.2010.12.006

Öner, A. (2008). Veri zarflama analizi ve finans sektöründe bir uygulama (Yayın No. 227100) [Yüksek Lisans Tezi, Marmara Üniversitesi] Yüksek Öğretim Kurumu Tez Merkezi. https://tez.yok.gov.tr/UlusalTezMerkezi/tezSorguSonucYeni.jsp

Özata, M., \& Sevinç, İ. (2010). Konya'daki sağlık ocaklarının etkinlik düzeylerinin veri zarflama analizi yöntemiyle değerlendirilmesi. Atatürk Üniversitesi İktisadi ve İdari Bilimler Dergisi, 24(1), 77-87. https://dergipark.org.tr/tr/download/article-file/30283

Öztürk, Y. E. (2009). Türk sağglk sektörü içerisindeki üniversite hastanelerinin etkinliklerinin artırılmasında dış kaynak kullanımı uygulamasının etkisi üzerine veri zarflama analizine dayalı bir araştırma (Yayın No. 249998) [Doktora Tezi, Selçuk Üniversitesi] Yüksek Öğretim Kurumu Tez Merkezi. https://tez.yok.gov.tr/UlusalTezMerkezi/tezDetay.jsp?id=ODNHq4khFyh01dBYydDWtA\&no= niB imQBGwK 1 yzrzVPog

Rajasulochana, S., \& Dash, U. (2012). Technical efficiency of comprehensive emergency obstetric and new-born care centres in Tamil Nadu. Journal of Health Management, 14(2), 151-160. https://doi.org/10.1177/097206341201400205

Savaş, F. (2015). Veri zarflama analizi. B. F. Yıldırım, \& E. Önder (Ed.), Çok kriterli karar verme yöntemleri. Dora Yayınevi.

Stefko, R., Gavurova, B., \& Kocisova, K. (2018). Healthcare efficiency assessment using DEA analysis in the Slovak Republic. Health Economics Review, 8(1), 1-12. https://healtheconomicsreview.biomedcentral.com/articles/10.1186/s13561-018-0191-9

Tütek, H., Gümüşoğlu, Ş. \& Özdemir, A. (2012). Sayısal yöntemler-yönetsel yaklaşım. Beta.

Weng, S. J., Wu, T., Blackhurs, J., \& Mackulak, G. (2009). An extended DEA model for hospital performance evaluation and improvement. Health Services and Outcomes Research Methodology, 9(1), 39-53. https://asu.pure.elsevier.com/en/publications/an-extended-deamodel-for-hospital-performance-evaluation-and-imp

Yavuz, B. (2012). Veri zarflama analizi yöntemi ile OECD ülkeleri etkinlik değerlendirmesi (Yayın No. 310544) [Yüksek Lisans Tezi, İstanbul Teknik Üniversitesi] Yüksek Öğretim Kurumu Tez Merkezi. https://tez.yok.gov.tr/UlusalTezMerkezi/tezDetay.jsp?id=c2ufO0hxsXxWvGZ0c5uSYA\&no=h qKBt3dvlF IKA7hk4xDQg

Yolalan, R. (1993). Işsletmelerarası göreli etkinlik ölçümü. Milli Prodüktivite Merkezi Yayınları No:483, Ankara. 


\section{EK}

Tablo 1: Hastane İsimleri Kısaltmaları

\begin{tabular}{|c|c|}
\hline Hastane İsimleri Kısaltmaları & Hastane İsimleri \\
\hline Aliağa DH & Aliağa Devlet Hastanesi \\
\hline Aliağa CİK DH & Aliağa Ceza İnfaz Kurumları Kampüs Devlet Hastanesi \\
\hline Bayındır DH & Bayındır Devlet Hastanesi \\
\hline Bergama DH & Bergama Dr. Faruk İlker Devlet Hastanesi \\
\hline Bornova DH & Bornova Türkan Özilhan Devlet Hastanesi \\
\hline Buca DH & Buca Seyfi Demirsoy Devlet Hastanesi \\
\hline Buca KDÇH & Buca Kadın Doğum ve Çocuk Hastalıkları Hastanesi \\
\hline Çeşme DH & Çeşme Devlet Hastanesi \\
\hline Çiğli DH & Çiğli Devlet Hastanesi \\
\hline Dikili DH & Dikili Devlet Hastanesi \\
\hline Foça DH & Foça Devlet Hastanesi \\
\hline Gaziemir DH & Gaziemir Nevvar Salih İşgören Devlet Hastanesi \\
\hline Katip Çelebi Ü. EAH & Katip Çelebi Üniversitesi Atatürk Eğitim Ve Araştırma Hastanesi \\
\hline Bozyaka EAH & Bozyaka Eğitim ve Araştırma Hastanesi \\
\hline Karşıyaka DH & Karşıyaka Devlet Hastanesi \\
\hline Kemalpaşa DH & Kemalpaşa Devlet Hastanesi \\
\hline Kiraz DH & Kiraz Devlet Hastanesi \\
\hline Dr. Behçet Uz ÇH & Dr. Behçet Uz Çocuk Hastalıkları ve Cerrahisi Eğitim ve Araştırma Hastanesi \\
\hline Dr. Suat Seren Göğ. & Dr. Suat Seren Göğüs Hastalıkları ve Cerrahisi Eğitim ve Araştırma Hastanesi \\
\hline Alsancak DH & Alsancak Nevvar Salih İşgören Devlet Hastanesi \\
\hline Tepecik EAH & Tepecik Eğitim ve Araştırma Hastanesi \\
\hline Menemen DH & Menemen Devlet Hastanesi \\
\hline Ödemiş DH & Ödemiş Devlet Hastanesi \\
\hline Seferihisar DH & Seferihisar Nejat Hepkon Devlet Hastanesi \\
\hline Selçuk DH & Selçuk Devlet Hastanesi \\
\hline Tire DH & Tire Devlet Hastanesi \\
\hline Torbali DH & Torbalı M. Enver Şenerdem Devlet Hastanesi \\
\hline Urla DH & Urla Devlet Hastanesi \\
\hline
\end{tabular}

